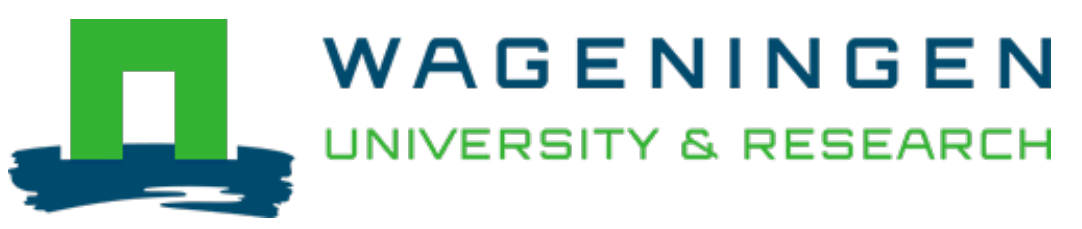

\title{
Influence of some process variables and storage conditions on the quality and shelf-life of soybean tempeh
}

Antonie van Leeuwenhoek: Nederlandsch tijdschrift voor hygiëne, microbiologie en serologie

Nout, M.J.R.; Bonants-van Laarhoven, T.M.G.; Dreu, J.; Gerats, I.A.G.M.

https://doi.org/10.1007/BF00404518

This publication is made publicly available in the institutional repository of Wageningen University and Research, under the terms of article $25 \mathrm{fa}$ of the Dutch Copyright Act, also known as the Amendment Taverne. This has been done with explicit consent by the author.

Article 25 fa states that the author of a short scientific work funded either wholly or partially by Dutch public funds is entitled to make that work publicly available for no consideration following a reasonable period of time after the work was first published, provided that clear reference is made to the source of the first publication of the work.

This publication is distributed under The Association of Universities in the Netherlands (VSNU) 'Article $25 \mathrm{fa}$ implementation' project. In this project research outputs of researchers employed by Dutch Universities that comply with the legal requirements of Article $25 \mathrm{fa}$ of the Dutch Copyright Act are distributed online and free of cost or other barriers in institutional repositories. Research outputs are distributed six months after their first online publication in the original published version and with proper attribution to the source of the original publication.

You are permitted to download and use the publication for personal purposes. All rights remain with the author(s) and / or copyright owner(s) of this work. Any use of the publication or parts of it other than authorised under article $25 \mathrm{fa}$ of the Dutch Copyright act is prohibited. Wageningen University \& Research and the author(s) of this publication shall not be held responsible or liable for any damages resulting from your (re)use of this publication.

For questions regarding the public availability of this publication please contact openscience.library@wur.nl 
The influence of some process variables and storage conditions on the quality and shelf-life of soybean tempeh

\author{
M. J. R. Nout, T. M. G. Bonants-Van Laarhoven, R. De Dreu and \\ I. A. G. M. GERATS \\ Department of Food Science, Agricultural University, De Dreijen 12, 6703 BC Wageningen, \\ The Netherlands
}

Aspects of traditional and experimental tempeh-manufacture have been reviewed by Ko Swan Djien and Hesseltine (1979). In the Netherlands, the commercial distribution and marketing of tempeh are hindered by its limited shelf-life. This report deals with preliminary studies on the effects of soaking, heating and inoculation procedures on the quality of freshly made and stored tempeh.

The soybeans used were of the type used by Dutch commercial tempeh-producers and had been dehulled by dry abrasion. Traditional tempeh starter from Semarang, Indonesia, as well as a pure culture inoculum of Rhizopus oligosporus NRRL 5905, were used.

Consistency measurements were carried out with a recording universal testing machine, type $\mathbf{S}$ 100 (Overload Dynamics, Schiedam, The Netherlands). Colour measurements were made with a colour difference meter, type D 25-3 (Hunter Lab, Fairfax, VA, U.S.A.).

Based on subjective panel assessments and instrumental analyses, the following criteria for tempeh of excellent consumer acceptability were drawn up. Raw (uncooked) tempeh should have a consistency corresponding to a force of 1.5-2.5 N required to break a cylindrical sample of $50 \mathrm{~mm}$ 
length and $15 \mathrm{~mm}$ diam suspended at its extremities; the colour of its surface should have the following characteristics: $\mathrm{L}=78-83, \mathrm{~b}-\mathrm{a}=12-14$; the $\mathrm{pH}$ of a suspension made with two parts of distilled water should be 6.0-6.6. In addition, cooked tempeh of excellent consumer acceptability should have a neutral, soy-like, or sweet taste and a neutral, soy-like, or slightly nutty odour.

In two factory processes studied soaking was accompanied with an approximately 1000 -fold increase of the total count of aerobic microorganisms. The soaked beans had $\mathrm{pH}$-values ranging from 4.5 to 6.2. In laboratory experiments, the acidifying microflora survived an initial soak water temperature of $70^{\circ} \mathrm{C}$, but acidification did not result in soak water with an initial temperature of $100^{\circ} \mathrm{C}$. In order to achieve maximum souring and to prevent the formation of objectionable off-odours, a soybean/water ratio of $\leqslant 3.5$ was required, causing the beans to remain permanently immersed. The lowest $\mathrm{pH}$ of the beans was achieved after a 16-h incubation at $30^{\circ} \mathrm{C}(\mathrm{pH} 4.8-5.2)$. Such souring was accompanied with high total bacterial counts of the beans $\left(2.0 \cdot 10^{8}-2.0 \cdot 10^{9} \cdot \mathrm{g}^{-1}\right)$ and increased viscosity of the soak water. After a 16 -h soak at $30^{\circ} \mathrm{C}$ in $1 \%$ lactic acid solution as proposed by Steinkraus et al. (1965), the beans had a pH of 4.85 and a relatively low total microbial count $\left(<10^{2} \cdot \mathrm{g}^{-1}\right)$.

The primary objectives of the heat treatment (either by boiling or steaming) are the removal of bitter-tasting substances and the achievement of a desirable texture of the beans. These objectives could be met by boiling at $95^{\circ} \mathrm{C}$ for at least $15 \mathrm{~min}$. The effect of this heat treatment on the microflora of soaked and fermented beans was investigated by soaking $24 \mathrm{~h}$ at $30^{\circ} \mathrm{C}$ followed by heating, and incubation for $48 \mathrm{~h}$ at $30^{\circ} \mathrm{C}$ under aseptic conditions. Heating for $15 \mathrm{~min}$ at $95^{\circ} \mathrm{C}$ resulted in survival and subsequent growth of a mixed culture of non-sporeforming acid-producing grampositive rods and cocci, and Bacillus spp. A moderate degree of spoilage of the incubated beans was observed; their $\mathrm{pH}$ increased from 6.5 (initial) to 7.7 . Heating for 30 or $60 \mathrm{~min}$ at $95^{\circ} \mathrm{C}$, or $15 \mathrm{~min}$ at $121^{\circ} \mathrm{C}$ (autoclave) resulted, however, in survival and subsequent growth of predominantly Bacillus spp., which caused extensive proteolytic spoilage and a $\mathrm{pH}$-increase to 8.35. More severe heat treatments eventually resulted in sterility, but the bean texture was strongly impaired and, if autoclaved, colour and odour defects rendered the beans unacceptable. On the other hand, beans of practical sterility and of acceptable colour and texture could be obtained by omitting the soaking stage altogether, and boiling the raw beans in $1 \%$ lactic acid for $20 \mathrm{~min}$ at $95^{\circ} \mathrm{C}$.

Beans were pretreated either by a 24 -h soak at $30^{\circ} \mathrm{C}$ followed by boiling for $15 \mathrm{~min}$ at $95^{\circ} \mathrm{C}$ (treatment I), or by boiling for $20 \mathrm{~min}$ at $95^{\circ} \mathrm{C}$ in $1 \%$ lactic acid (treatment II). Subsequently, the pretreated beans were inoculated with approximately $10^{6}$ fungal propagules per gram of cooked

Table 1. Effect of bean pretreatment and inoculation procedures on overall quality scores and bacterial counts of freshly-made tempeh

\begin{tabular}{|c|c|c|c|}
\hline \multirow[t]{2}{*}{ Inoculation ${ }^{1}$} & \multirow{2}{*}{$\begin{array}{l}\text { Parameters } \\
\text { measured }\end{array}$} & \multicolumn{2}{|c|}{ Pretreatment ${ }^{2}$} \\
\hline & & I & II \\
\hline A & $\begin{array}{l}\text { overall quality score } \\
\text { total bacterial count per gram } \\
\text { number of bacterial spores per gram }\end{array}$ & $\begin{array}{l}8.1 \\
6.3 \cdot 10^{9} \\
4.0 \cdot 10^{6}\end{array}$ & $\begin{array}{l}5.5 \\
5.0 \cdot 10^{9} \\
4.8 \cdot 10^{6}\end{array}$ \\
\hline B & $\begin{array}{l}\text { overall quality score } \\
\text { total bacterial count per gram } \\
\text { number of bacterial spores per gram }\end{array}$ & $\begin{array}{l}8.0 \\
1.3 \cdot 10^{10} \\
2.5 \cdot 10^{7}\end{array}$ & $\begin{array}{l}6.5 \\
4.0 \cdot 10^{5} \\
1.3 \cdot 10^{2}\end{array}$ \\
\hline
\end{tabular}

${ }^{1} \mathrm{~A}$, traditional tempeh starter, under non-sterile conditions; B, pure culture of Rhizopus oligosporus, under hygienic conditions (see text).

${ }^{2} \mathrm{I}$, soaking at $30^{\circ} \mathrm{C}$ for $24 \mathrm{~h}$, followed by boiling at $95^{\circ} \mathrm{C}$ for $15 \mathrm{~min}$; II, boiling at $95^{\circ} \mathrm{C}$ for 20 $\min$ in $1 \%$ lactid acid. 
beans, using either the traditional tempeh starter, under non-sterile conditions (treatment $A$ ), or a spore suspension of the pure culture of $R$. oligosporus (treatment B), under hygienic conditions employing sterilized utensils in a laminar air-flow cabinet. The inoculated beans were packed in sanitized and perforated containers and incubated at $30^{\circ} \mathrm{C}$ for $48 \mathrm{~h}$. Overall quality scores (means of scores given for exterior, degree of discolouration by sporulation, firmness, degree of mycelial growth in the centre of the tempeh block, odour, $\mathrm{pH}$, colour characteristics, break force, and taste after cooking) of the freshly made tempehs resulting from pretreatment I were significantly higher as shown in Table 1. Thus, the soaking stage and/or the microflora of the soaked beans surviving the heat treatment may be essential for freshly made tempeh of good quality.

The effects of the two inoculation procedures on the quality of freshly made tempeh did not differ significantly. Only one combination of treatments, viz. pretreatment I followed by inoculation procedure B, resulted in freshly made tempeh with relatively low bacterial counts (see Table 1). However, it can be seen that, even when starting with sterile beans and working under hygienic conditions with a pure culture of fungal spores, we were not able to obtain tempehs with bacterial counts below $10^{5} \cdot \mathrm{g}^{-1}$. Due to the nature of the cooling operation of the cooked beans which could not be carried out under sterile conditions without unwanted accumulation of moisture due to condensation in the beans, minor contamination is the cause of the bacterial counts mentioned. All other combinations resulted in tempeh with high bacterial counts, approximating those of commercially available tempeh which had total bacterial counts between $6.3 \cdot 10^{7}$ and $5.0 \cdot 10^{9} \cdot \mathrm{g}^{-1}$, counts of bacterial spores between $1.0 \cdot 10^{3}$ and $6.3 \cdot 10^{6} \cdot \mathrm{g}^{-1}$, and yeast counts between $<10$ and $1.3 \cdot 10^{8} \cdot \mathrm{g}^{-1}$. From such commercial samples, most bacterial isolates were classified as Bacillus, Enterobacteriaceae, Staphylococcus, Aeromonas and Aerococcus spp.

Freshly made tempehs resulting from combinations of treatments I + A (traditional procedure) and $\mathrm{II}+\mathrm{B}$ (yielding tempeh with relatively low bacterial counts) were stored for up to 14 days at $3{ }^{\circ} \mathrm{C}, 10^{\circ} \mathrm{C}$ and $21^{\circ} \mathrm{C}$. Freshly made traditional tempeh (treatments $\mathrm{I}+\mathrm{A}$ ) had very high initial bacterial counts (see Table 1) which did not increase further during storage, even at $21^{\circ} \mathrm{C}$. The decline of its overall quality score from 8.1 (initial) to $3.8\left(21^{\circ} \mathrm{C}, 3\right.$ days of storage), $4.2\left(10^{\circ} \mathrm{C}\right.$, 7 days of storage) or $4.7\left(3^{\circ} \mathrm{C}, 14\right.$ days of storage) was much faster than that of tempeh made by treatments II + B. Total bacterial counts of the latter increased from their initial value (Table 1) to $7.9 \cdot 10^{7} \cdot \mathrm{g}^{-1}\left(21^{\circ} \mathrm{C}, 3\right.$ days of storage) or $1.6 \cdot 10^{7} \cdot \mathrm{g}^{-1}\left(10^{\circ} \mathrm{C}, 7\right.$ days of storage), whereas its counts of bacterial spores increased from their initial value (Table 1) to $1.6 \cdot 10^{4} \cdot \mathrm{g}^{-1}\left(21^{\circ} \mathrm{C}\right.$, 3 days of storage) or $6.3 \cdot 10^{3} \cdot \mathrm{g}^{-1}\left(10^{\circ} \mathrm{C}, 7\right.$ days of storage). At $3^{\circ} \mathrm{C}$, the bacterial counts of this tempeh did not increase significantly.

Overall quality scores of the tempeh made by treatments II $+\mathrm{B}$ remained constant at 6.5 during storage at $3^{\circ} \mathrm{C}$ for 14 days, at $10^{\circ} \mathrm{C}$ for 7 days, or at $21^{\circ} \mathrm{C}$ for 3 days. Loss of firmness was found to be a factor contributing to the limited shelf-life of both types of tempeh. Although tempeh from I + A softened faster than that from II + B at all storage temperatures, the consistency of both types was rated unacceptable (breaking force $\leqslant 0.5 \mathrm{~N}$ ) after 14 days at all tested storage temperatures.

Ko Swan Disen and Hesseltine, C. W. 1979. Tempeh and related foods. p. 115-140. In A. H. Rose (ed.), Microbial Biomass, Economic Microbiology, Vol. 4. - Academic Press, London.

Steinkraus, K. H., Van Buren, J. P., Hackler, L. R. and Hand, D. B. 1965. A pilot-plant process for the production of dehydrated tempeh. - Food Technol. (Chicago) 19 (1): 63-68. 